\title{
Functioning and Development of Target Capitals of Non-profit Organizations
}

\author{
Elena V. Bokareva ${ }^{1}$, Lyudmila I. Chernikova ${ }^{1}$, Elena N. Egorova ${ }^{1} \&$ Stella K. Egorova ${ }^{2}$ \\ ${ }^{1}$ Russian State University of Tourism and Service, Cherkizovo, Moscow region, the Russian Federation \\ ${ }^{2}$ Moscow Institute of State and Corporation Management, Moscow, the Russian Federation
}

Correspondence: Elena N. Egorova, Russian State University of Tourism and Service, Glavnaya st., 99, Cherkizovo, Pushkinsky district, Moscow region, the Russian Federation. Tel: 7-495-940-8349. E-mail: egelni@yandex.ru

Received: August 1, 2014 Accepted: September 10, 2014 Online Published: November 14, 2014

doi:10.5539/ass.v10n23p223 URL: http://dx.doi.org/10.5539/ass.v10n23p223

\begin{abstract}
The article performs the results of research, functioning and development of target capitals of non-profit organizations. An overview of legislative base, declaring an order of formation of formation of target capitals, participators of this process and conditions of work of target capital is provided. Analysis of statistic data allows the authors to make a conclusion that dynamics of quantity of target capitals remains the same during the last three years, at that the main volume of them belongs to the educational sphere. In the world practice, endowment can be completed by charity in the form of non-movable assets, stocks, objects of art, etc. In Russia the resolving list of charities into target capital was widened just with adoption of Federal Law 'On introduction of changes in separate legislative acts of Russian Federation with regard of formation and using of target capital of non-profit organizations' of 21.11.2011 N 328-FZ. The article discussed the model of development of Russian target capitals (endowmnent-funds). Perspectives of their development and their problems are described. During the research it was suggested to divide the problems into two groups: absence of donors, ready to finance the strategic needs of non-profit sector, should be related to the first group, the second should include length of operation, which does not give an opportunity of solving the problem of receiver of financial funds in a short period of time. In the conclusion of the article, it is grounded that for the further development of target capitals in Russia it is necessary to introduce changes both in legislative normative documents and in work of non-profit organizations.
\end{abstract}

Keywords: endowmnent-fund, fundraising system, fund, competition, non-profit organization, target capital

\section{Introduction}

In Russia creation of a target capital (TC) became possible since 2007, when Federal Law of 30 December 2006 $\mathrm{N}$ 275-FZ 'On order of formation and using of target capital of non-profit organization', further Law, came into force.

Target capital, or endowmnent, is 'formed on the account of charity a part of property of non-profit organization, delivered in trust management to a managing company for receiving revenue, used for financing statutory activity of non-profit organization'.

Target capital is a property of a non-profit organization (NPO) and cannot be confiscated by other organizations. Disestablishment of TC is possible just by the reasons, listed in the article 14 of the Law.

Target capital is a part of the property of a non-profit organization, formed due to charity, paid in by donor (donors) in the form of financial funds, delivered in trust management to a managing company for receiving revenue, used for financing statutory activity of non-profit organization. An owner of target capital, that is organization, which determines the fate of revenue, can be a non-profit organization, created in an organization legal form of a fund, autonomous non-profit organization, non-profit organization not having membership, established by citizens and (or) judicial persons on the basis on voluntary material contributions and which have social, charitable, cultural, educational and other socially useful aims. Non-profit organization without membership, created in a purpose of rendering services in the sphere of education, health protection, culture, 
science, right, social organization, social fund or religious organization. All other organization legal forms are legislatively deprived of the right of forming capital nowadays (Bokareva, 2013).

\section{Methods and Description of the Area}

The Law determines two variants of creation of target capitals. The first - non-profit organization itself establishes the capital and is simultaneously the receiver o the revenues from its using (Figure 1). This is the 'internal' variant of creation.

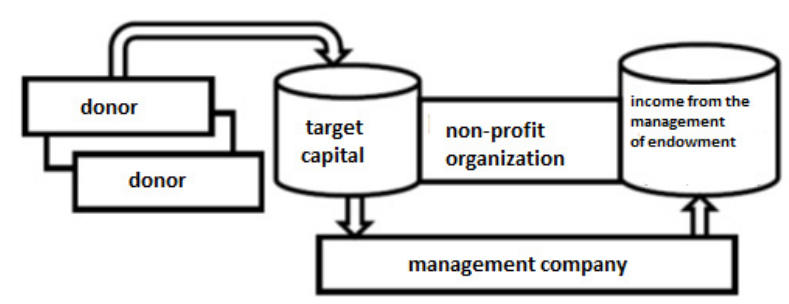

।

Figure 1. 'Internal' variant of creation of target capitals

The 'internal' variant can be chosen just by organization, created in organization legal form of fund, autonomous non-profit organization, social organization, social fund or religious organization.

If the target capital is created according to the first variant, then collection of contributions and all operations, related to management, excluding investing activity, are performed 'inside' of non-profit organization.

In this case fund of target capital is, just, contributions, taken by a special way. At formation - separate sum of money with purpose, while completing of existing target capital, when except money, securities, unmoved property can be taken as contributions - specially taken contributions with obligations of delivering them in trust management, with separate accounting, auditing, reporting, etc.

Another situation occurs in a case of choosing the second variant, when non-profit organization doesn't have any of listed organization legal forms.

In this case, a separate judicial person - specialized organization is created, that means a fund, performing all operations with target capital (Figure 2). This is an 'external' variant.

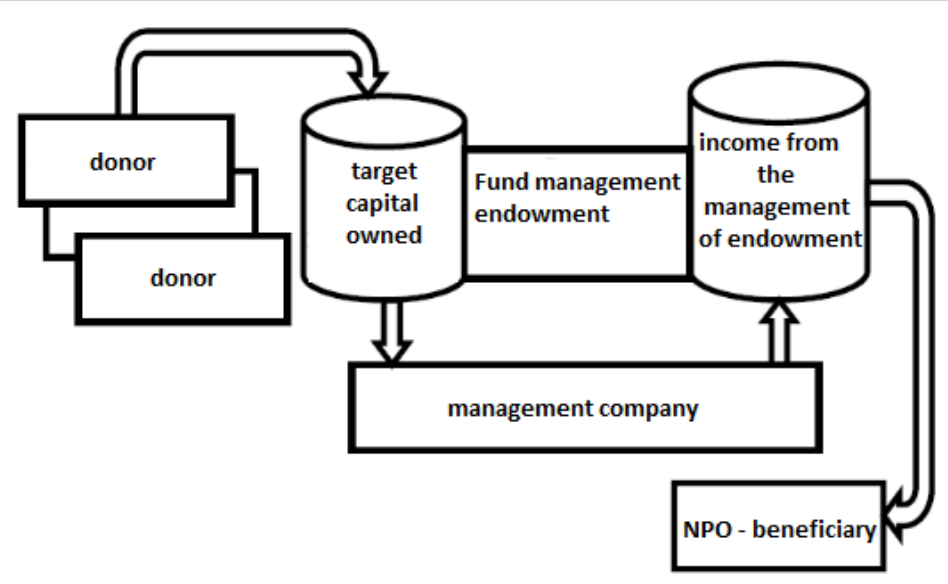

Figure 2. 'External' variant of creation of target capitals

The process of managing endowment in time is performed at Figure 3.

As the reference point 'decision-making on endowment formation' is taken. Checkpoint is 'state registration of necessary constituent documents'. The next is the point 'start of collecting donations'. The period of time between the set points we would 'preparatory'. 
The stage 'target capital formation' begins with the collection of funds to the trust capital. In order to perform the calculations related to receiving funds for formation and completion of target capital, deliverance of them in trust management, use of income, distribution of such income in favor of other recipients, a separate bank account is open (Bokareva \& Egorova, etc., 2014).

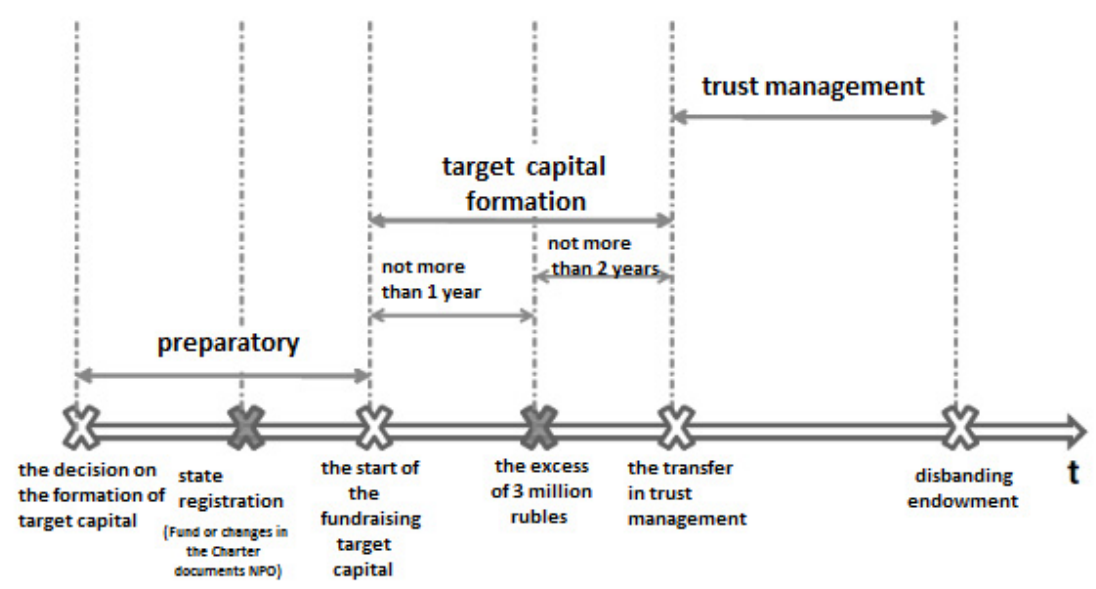

Figure 3. Process of management of target capital

Within two months from starting with the date, when the amount of financial funds received on the formation of target capital would be 3 million rub., a non-profit organization has to deliver the financial funds to the managing company. Starting with the date of delivering funds in trust management, target capital is considered to be formed. Hence, the next reference point - 'excess of 3 million rubles', and, accordingly, the following 'deliverance of target capital in trust management'. Target capital should obtain an identifying it symbol. From the point of 'deliverance in trust management' to the point of 'disestablishment of target capital' interval 'trust management' is defined.

\section{Results}

According to the Law, initial amount for the formation of target capital should be collected no later than one year starting with the date of receiving the first contribution. If the requirement is not met, the target capital is not formed and return of the received funds to the donor is necessary. During the period of formation, the donations received can be allocated on deposit accounts in credit institutions. Interest received from the allocation can be attached to the forming target capital. It is possible to pay attention once again to the fact that only after the target capital is formed, its completion can be carried out at the expense of the securities and unmoved property, formation can be performed only at the expense of financial funds. Thus, to receive securities or unmoved property, it is necessary to take first, at least 3 million rubles in the form of contributions, and to deliver them in trust management.

If to take into account the actual market rates on deposit contracts and time frames, allocated for formation of the target capital, the 'lion's share' of the required amount of 3 million rub. should be received.

More interesting is the situation in which a non-profit organization received a sufficient to form target capital sum of money ( 3 million rub. or more) and has an opportunity to increase the available contributions due to allocating them on deposit accounts. In accordance with the Law, organization has two months for delivering the financial funds in trust management.

In the case when additional contributions in the form of financial funds would be made in favour of a non-profit organization, deliverance of these funds in trust management should be carried out within 30 days of their receipt. Non-profit organization - owner of target has a right to complete it by the means of interest from allocation of financial funds on deposit accounts in credit institutions, received for formation and (or) completion of target capital. Consequently, a non-profit organization has a right to open a deposit and increase the collected funds. As it was already noted, works on formation and completion of target capital continue constantly, and the effect of its creation does not reflect immediately. Moreover, constant completion of the target capital by contributions is 
needed, which is difficult in the case of absence or insufficient development of the channels of interaction with donors.

Target capital allows business representatives to maintain the priority projects, to control the distribution of funds from management of target capital (donors, whose contributions exceed $10 \%$ of the target capital, have a right to enter the Council on the use of target capital). Funds contributed to target capital, and incomes from the management of the target capital are not taxed. Donors - individuals, transmitting funds to target capital, are provided with social tax deduction from tax on income of individuals. In some regions of the Russian Federation tax benefits for corporate persons - donors are provided. Target capital can be a tool of effective and long-term co-financing (with state funds) social sphere by extra budgetary resources (Egorova, 2011).

Ministry of Economic Development of Russian Federation provides subsidies from the federal budget to the budgets of the subjects of the Russian Federation on the realization of programs to support socially oriented non-profit organizations in the presence of target capital in the regions (Egorova, 2012).

Target capital is formed for a period of not less than 10 years. In Russia, most target capitals were established for an unlimited period, but there are target capitals for 10, 20, 50 years. Presence of mission and strategy of development of organization in the long run, understanding which volume of target capital is necessary for the functioning of organization, is important. Target capital is formed by contributions. Own funds, earnings, other funds of organizations, which create funds of target capital cannot be related to target capital. Funds of target capital themselves cannot donate to formation or completion of their target capitals. At the stage of formation of target capital, it is possible to donate just money, since 2012, when the amendment of the Law came into force, completion of capital target is possible by the means of securities and unmoved property. Meanwhile, the main means of completion of target capital still remain financial funds.

In many countries, legislative support is given to organizations, forming target capital, which is a source of income, which is financing activities of the nonprofit sector. Thereby, a non-profit organization, created an endowment-fund receives a stable and long-term source of financing their activities. It should be borne in mind that capital itself during the process of fund activity is not spent, it is managed by third parties (Denmark, 2007; Ramachandra, 2008; Ramsden, 2008; Bokareva, 2013).

The most important feature, which should be kept in mind while creating target capital, is the fact that it is different from traditional forms of charity. One of the main factors underlying this difference is that the contributions, used for formation of endowment- funds, are needed not for financing current activity, but for investing in order to solve the long-term objectives.

The minimum size of the target capital ( 3 million) should be attracted within a year, it is necessary to create the supreme management body of the organization, choose a managing company, and then deliver the funds in trust management to the managing company. If within a year target capital does not reach the minimum amount, it is to be disestablished. Many nonprofit organizations face the so-called trap three million all resources go for attracting funds necessary for formation of target capital, but then significant increase of target capital does not work.

Desire to combine the strategic interests of donors with the interests of recipients of the target capital for the co-financing of social projects is the chief motive for the creation of endowment-funds in many cases. On the one hand, there is an assumption that large private contributions in view for long-term investment and use can be considered as an effective means, encouraging acquisition of respect from side of the society. On the other hand, it is believed that the rapid spread of endowment-funds mechanism is possible only after the targeted guidance from above.

It is often suggested that transfer of funds aimed at formation of fund od target capital, allows to intensify impact on organization in a greater extent than the realization of a single contribution. However, it is difficult to accept. In the course of development of institute of endowment funds in Russia there are various kinds of obstacles. All the variety of problems that Russian non-profit organizations face during creation of endowment funds can be divided into two groups. On the one hand, there is no layer of philanthropists willing to allocate resources to the strategic needs of the nonprofit sector. On the other hand, recipients of financial funds often don't have an opportunity of waiting, as the problems to be solved in the short term, are too acutely for them. Target capital cannot be considered as the only mechanism by which it would be possible to solve all problems in those areas where it can be used. It acts only as one of many possible mechanisms that can reduce the burden on other participants of the relations in these areas. At the same time, it should be noted that target capital does not negate the obligation of the state to support such socially important spheres as education and health (Chernikova et al., 2011; Shitkov, 2010; Lavrova, 2010). 
As it was mentioned above, the activity of non-profit organization on use of endowment-funds in the Russian Federation is regulated by the Law. According to the given normative document it is possible to highlight the most significant aspects of formation of target capital:

1) In order to form target capital donors have a right to deliver funds to property of non-profit organization both in the currency of the Russian Federation and in foreign currency. Financial funds, received from them, can be transferred under the contract of contribution or will in accordance with the rules of civil legislation on donation or inheritance.

2) In order to complete formed target capital a non-profit organization may declare a public collection of money. Such a measure is valid on the basis of a standard form contribution contract, which in its turn before it is approved by the Council on use of the target capital and confirmed by the supreme management body according to the Law. There is a number of requirements to be observed by non-profit organizations, which are the owners of target capital. A nonprofit organization cannot begin to form a target capital without creating a council on use of target capital. Until the moment when the supreme managing body of the nonprofit organization does not approve the number and personal composition of council on use of the target capital, non-profit organization does not have a right to deliver the financial funds in trust management.

3) A nonprofit organization may form several target capitals, if donors or will set different goals of use of target capital, or on the basis of separate contribution contracts.

4) An important economic aspect is that the accounting of all transactions related to obtaining financial funds for formation of target capital, deliverance of funds, which make up target capital, in trust management to a managing company, as well as with use, distribution of revenue from target capital should be conducted separately.

5) The fundamental rule in the activity of a non-profit organizations can assume that it has no right to use and dispose the financial funds, received on formation of target capital (except for paid in them into deposits in credit organizations), till their deliverance in trust management to the managing company.

6) The Law prescribes the minimum size of target capital. Within two months from the date when the amount received by a non-profit organization on formation of target capital would be 3 million rub.., the non-profit organization should deliver financial funds in trust management to managing company. As soon as these funds would be available for the managing company, the target capital is considered to be formed.

Besides, in 2011, the Law on target capital and the Tax Code of the Russian Federation was amended, which filled gaps in the legislation, considered the suggestions of experts and practitioners, in particular, ability to complete target capital by securities and unmoved property.

Non-profit organizations have a legally vested right to spend a certain part of the property, which is included in the target capital. This part of the Law should not exceed the rate of $10 \%$ per annum of balance value of property, which forms target capital.

The main share in the structure of attracted resources of endowment-fund is taken by contributions; the main revenues are also incomes from operations in the financial markets.

Income and expense structure of endowment-fund reflects the specifics of his activities as a property complex formed by charitable contributions and is the largest institutional investor, management of which is performed by managing company (Bokareva, 2013).

The given structure of incomes and expenses is presented in Table 1.

Table 1. Incomes and expenses of endowment-fund

\begin{tabular}{ll}
\hline Incomes & Expenses \\
\hline $\begin{array}{l}\text { Income from transactions for their own } \\
\text { expense (profit from increased value of } \\
\text { securities) }\end{array}$ & $\begin{array}{l}\text { Remuneration of managing company (including employees' salary, } \\
\text { administrative expenses, fees for services provided by financial } \\
\text { intermediaries, legal services, etc.) }\end{array}$ \\
\cline { 1 - 2 } Dividends received & $\begin{array}{l}\text { Expenses on the maintenance of educational institutions, scholarships } \\
\text { and other programs }\end{array}$ \\
\hline $\begin{array}{ll}\text { Interest received (bonds, deposits) } \\
\text { property }\end{array}$ & Other expenses \\
\hline Other income &
\end{tabular}


Expenses incurred by the managing company while trust management of property, are covered by the income from trust management of property.

Endowment-fund yearly brings small incomes, but their advantage constitutes in that they are regular. For example, in 2010 the average profitability was $11-15 \%$ of endowments, in 2011 it did not exceed 10\%. In 2012, the profitability on preliminary estimates was about $10 \%$ too. This is related to the fact that while the assets of the funds are low, consequently the income from investment will not give a significant increase to the budget. At the same time, while foreign institutions of higher education receive from endowment-funds up to $40 \%$ of their budgets. In order to increase revenues from funds of target capital, the focus should be on effective fundraising, which operation is a whole science. It is necessary to create a special department, to prepare proposals for donors.

It is rational to draw up a financial plan of using capital for the owner of capital. Also, in this respect, it is recommended to specify the distribution revenue from use of capital, whereby it would be possible to avoid incorrect situations in the future. Financial planning, in this case, is necessary to be carried out, taking into account a number of important points which are:

1 The procedure of forming target capital;

2 Direction of target capital investments;

3 Planned total annual revenues;

4 Planned expenses in the form of distribution;

5 Changes in long-term financial plan.

If the law would be an effective instrument of charity, in Russia in the near future several hundreds of endowment funds would be created.

Subject of target capitals (endowments) is new to Russia; the Russian legislation in this area is a little more than 5 years.

According to the program 'endowments' Noncommercial Partnership of grant making organizations 'Donors Forum', there are about 130 endowment funds registered in Russia (as of May 30, 2014).

Registered FTCs are distributed by geographical location in the following way: Moscow - 55 organizations, St. Petersburg - 17, the other 29 regions - 45: Altay Region, Arkhangelsk Region, Republic of Bashkortostan, Buryatia, Volgograd Region, Vologda Region, Voronezh Region, Kemerovo Region, Krasnoyarsk Region, Kirov Region, Republic of Mordovia, Moscow Region, Nizhny Novgorod Region, Novosibirsk Region, Omsk Region, Orenburg Region, Penza, Perm Region, Primorsky Region, and others.

Ten largest Russian target capitals (according to public data as of September 2013):

1. Special fund of management of target capital 'Ural-Invest Plus';

2. Special fund of target capital of support and development of the Skolkovo Institute of Science and Technology (SkolkovoTech);

3. Special Fund of management of target capital for development of MGIMO

4. Fund of the European University in St. Petersburg (EUSPb);

5. Fund of management of target capital 'Development of St. Petersburg State University';

6. Charity fund of social support 'Dostoinstvo';

7. Fund of target capital 'Istoki';

8. Special Fund of management of target capital for fencing veterans support;

9. Children's Charity Fund 'Victoria';

10. Special Organization of Management of target capital - non-profit organization-owner of target capital 'Fund of target capital RES'

As it is seen from the list, the largest target capital funds are mainly funds, established for supporting institutions of higher education. In 2013, entirely new types of funds of target capital began to develop in Russia. It is the capital of the community foundation, 'Grazhdansky Soyuz', the combined target capital for support NPOs of Penza region. Also endowment of School of A. Gorchakov was formed, Russia's first target capital for support of a private high school.

Slightly more than a half of the registered funds have already formed target capital, and the rest are in the process of attracting contributions. By the spheres of support registered target capital funds are distributed in the following way (in percentage): education and science operates approximately $71 \%$ of the funds; in the sphere of health and social support of population - about $15 \%$; in the sphere of culture and art - about $11 \%$; and the sphere 
of sport - 3\%. The total amount of financial funds accumulated by target capitals in Russia, is more than 25 billion rubles. The largest target capital funds are created to support universities. For an institutions of higher education target capital can be both a 'safety cushion', which guarantees an additional income, and the source of financing of innovation and long-term programs. (Bokareva, \& Egorova, etc., 2014).

\section{Conclusion}

The model of development of Russian target capitals (endowment funds) becomes more popular. The main factors underlying this kind of attention are: the increase of number of round tables, seminars, sections, conferences, devoted to the subject of target capitals, increase of public understanding of the importance of target capital model, growth of Russian endowment-funds, their regional distribution and growth of media interest in this topic.

However, analysis of the awareness of endowment fund, conducted among potential donors, detected several significant problems.

The research established that $92.8 \%$ of respondents never heard of an endowment-fund, which indicates a low awareness on this topic. It was also revealed that $32.1 \%$ of respondents know which benefits they can get by the use of the specific capital. Potential donors are $11.7 \%$, this figure is very low, but it should be noted that it is higher than the number of knowledgeable.

Thereby, in Russia the mechanism of target capital just started lining up. It can be one of the main tools for attracting non-state resources in the sphere of higher education and, in general, on financing of social projects. However, new ways of economic stimulating of donors are needed in order to interest the private sector in development of non-profit organizations. And development of regulatory accounting transactions, related to target capital and reporting forms for non-profit organizations, is needed.

\section{References}

Bokareva, E. V. (2013a). Target capital of non-profit organization: world experience of use and standard regulation in modern Russia. Financial analytics: Problems and decisions, 15, 43-47.

Bokareva, E. V. (2013b). The analysis and evaluation of the work of funds of the target capital in Russia. Financial analytics: Problems and decisions, 21, 7-10.

Bokareva, E. V., Egorova, E. N., Kuchin, M. A., \& Chernikova, L. I. (2014). Features of management of the target capital in system of the higher education. Service in Russia and abroad, m.8, 5(52), 184-195.

Core J., Guay, W., \& Verdi, R. (2006). Agency problems of excess endowment holdings in not-for-profit firms. Journal of accounting and economics, 41. http://dx.doi.org/10.1016/j.jacceco.2006.02.001

Chernikova, L. I., \& Zayernyuk, B. M. (2011). New funding mechanisms for Russian education. Bulletin of Association of higher education institutions of tourism and service, 1, 52-57.

Denmark, F. (2007). Marking the Grade. Institutional Investor's alpha. July-August.

Egorova, E. N. (2011). Fiscal monitoring as information base of tax regulation. Plus service, 1, 87-93.

Egorova, E. N. (2012). Tax incentives of innovative activity in Russia. Service in Russia and abroad, 7(34), 112-123.

Egorova, S. K. (2012). Innovations in information support of management of subjects of small business of a services sector. Messenger of Volga region state university of service. Series: Economy, 21, 87-95.

Lavrova, P. (2010). Some aspects of creation of high school endaument-fund: Practical advicel/the Theory and practice of functioning of funds of the target capital in the higher education of Russia. The collection of practical recommendations for participants of the International scientific and practical conference "The Theory and Practice of Functioning of Funds of the Target Capital in Russia", MGIMO (At) the MFA of Russia, on April 27-29, 2010 / Under. edition of E. S. Biryukov, D. A. Degterev, A. V. Stelmakh. - M.: MGIMO.

Ramachandra, S. (2008). Higher education and non-profit governance: The role of endowment. May.

Ramsden, D. (2008). Insights into the Yale formula for endowment spending. Yale magazine, 4.

Shitkov, C. B. (2010). Procedure of registration of endaument-funds of higher educational institutions for the Russian legislation//the Theory and practice of functioning of funds of the target capital in the higher education of Russia. The collection of practical recommendations for participants of the International scientific and practical conference "The Theory and Practice of Functioning of Funds Tselevokgo the 
Capital in Russia", MGIMO (At) the MFA of Russia, on April 27-29, 2010 / under. edition of E. S. Biryukov, D. A. Degterev, A. V. Stelmakh. - M.: MGIMO, 2010.

The federal law Russian Federations of December 30, 2006. No. 275-FZ "About an order of formation and use of the target capital of non-profit organizations".

The federal law of July 23, 2013. No. 251-FZ "About modification of separate acts of the Russian Federation in connection with transfer to the Central bank of the Russian Federation of powers on regulation, control and supervision in the sphere of the financial markets" (with changes and additions).

\section{Copyrights}

Copyright for this article is retained by the author(s), with first publication rights granted to the journal.

This is an open-access article distributed under the terms and conditions of the Creative Commons Attribution license (http://creativecommons.org/licenses/by/3.0/). 